\title{
The effect of tile-drainage on nitrous oxide emissions from soils and drainage streams in a cropped landscape in Central France
}

\author{
Agnès Grossel ${ }^{\mathrm{a}, *}$, Bernard Nicoullaud ${ }^{\mathrm{a}}$, Hocine Bourennane ${ }^{\mathrm{a}}$, Marine Lacoste ${ }^{\mathrm{a}}$, \\ Christophe Guimbaud $^{\mathrm{b}}$, Claude Robert ${ }^{\mathrm{b}}$, Catherine Hénault ${ }^{\mathrm{a}}$ \\ ${ }^{a}$ URSOLS, INRA, 45075 Orléans, France \\ ${ }^{\mathrm{b}}$ Laboratoire de Physique et de Chimie de l'Environnement et de l'Espace LPC2E UMR 7328 CNRS/Université d'Orléans 3A, Avenue de la Recherche scientifique, \\ 45071 Orléans Cedex 2, France
}

Keywords:

Greenhouse gas

Artificial drainage

Indirect emission

Surface water

\begin{abstract}
A B S T R A C T
Tile drainage may have contrasting effects on soil nitrous oxide $\left(\mathrm{N}_{2} \mathrm{O}\right)$ emission. Because drainage decreases anoxic periods in soils, it could reduce $\mathrm{N}_{2} \mathrm{O}$ production via denitrification and also limit the reduction of $\mathrm{N}_{2} \mathrm{O}$ into nitrogen gas $\left(\mathrm{N}_{2}\right)$. Moreover, drainage accelerates the discharge of water enriched in dissolved $\mathrm{N}_{2} \mathrm{O}$ and mineral nitrogen. Thus, nitrogen losses and $\mathrm{N}_{2} \mathrm{O}$ releases from discharged surface water need to be quantified to assess the total effect of drainage on $\mathrm{N}_{2} \mathrm{O}$ emissions. Thus, the objectives of this study were two-fold: (1) to assess the effect of tile-drainage on soil $\mathrm{N}_{2} \mathrm{O}$ emissions in an agricultural area in Central France (direct emissions) and (2) to compare emissions from soils and from the stream draining the area (indirect emissions). The emissions of $\mathrm{N}_{2} \mathrm{O}$ by soils were measured using static chambers in two drained and two undrained cereal plots over two growing seasons. A rule-based model was fitted to identify the influence of drainage and ancillary variables. Stream $\mathrm{N}_{2} \mathrm{O}$ emissions were measured with a floating chamber during one growing season. The mean direct $\mathrm{N}_{2} \mathrm{O}$ emissions were $0.071 \mathrm{mg} \mathrm{N} \mathrm{m}^{-2} \mathrm{~h}^{-1}$ and were larger in the undrained plots than in the drained plots in both growing seasons $(p<0.001)$. The rule-based model showed that the drainage effect on $\mathrm{N}_{2} \mathrm{O}$ emissions was dominant over the permanent soil variables. The mean stream $\mathrm{N}_{2} \mathrm{O}$ emissions were $0.190 \mathrm{mg} \mathrm{N} \mathrm{m}^{-2} \mathrm{~h}^{-1}$. The surface water emissions represented $31 \mathrm{kgN}$ during the flow period ( 7 months) while direct emissions were $1846 \mathrm{~kg} \mathrm{~N}$ during the same period. Thus, indirect emissions accounted for $<2 \%$ of the total $\mathrm{N}_{2} \mathrm{O}$ emissions in the study site. While tile-drainage did not result in significant indirect emissions at this local site scale, it was identified as the dominant factor controlling the direct soil $\mathrm{N}_{2} \mathrm{O}$ emissions. Thus, drainage should be taken into account in greenhouse gas emission inventories for larger areas.
\end{abstract}

\section{Introduction}

Artificial drainage of hydromorphic soils is common in cropped areas to remove excess water from soils. Drainage has been installed in approximately $11 \%$ of France's agricultural areas, with $23 \%$ of the drained areas in the Centre region (Agreste 2012AR26, recensement agricole 2010). Soil nitrous oxide $\left(\mathrm{N}_{2} \mathrm{O}\right)$ emissions are highly dependent on soil aeration status. $\mathrm{N}_{2} \mathrm{O}$ is produced in soil by different microbial processes, mainly nitrification, i.e., oxidation of ammonium $\left(\mathrm{NH}_{4}{ }^{+}\right)$to nitrite $\left(\mathrm{NO}_{2}{ }^{-}\right)$and then to nitrate $\left(\mathrm{NO}_{3}{ }^{-}\right)$, and denitrification, i.e., reduction of nitrate to $\mathrm{N}_{2} \mathrm{O}$ and ultimately to nitrogen gas $\left(\mathrm{N}_{2}\right)$ (Smith et al., 2003). Anoxia promotes denitrification, which may dominate $\mathrm{N}_{2} \mathrm{O}$ production in the soils (Dobbie and Smith, 2001). Thus, installation of artificial drainage, which decreases anoxic periods, is expected to decrease the total $\mathrm{N}_{2} \mathrm{O}$ emission (Bouwman, 1996; Dobbie and Smith, 2006).

However, maximum $\mathrm{N}_{2} \mathrm{O}$ emission rates are generally observed for water-filled pore space (WFPS) $<90 \%$ (Davidson and Verchot, 2000; Castellano et al., 2010), i.e., for unsaturated soils, because of the slower diffusion of gas and the possible further reduction of $\mathrm{N}_{2} \mathrm{O}$ at higher WFPS (Smith et al., 2003). This may explain why larger $\mathrm{N}_{2} \mathrm{O}$ emissions have been measured in drained soils than in undrained soils under grassland (van Beek et al., 2010) or under forest (von Arnold et al., 2005; Jungkunst and Fielder, 2007). A review of the $\mathrm{N}_{2} \mathrm{O}$ emissions studies from German soils has also suggested that under cultivation, regularly water-logged soils showed lower emissions than well-aerated soils (Jungkunst et al., 2006). Direct comparisons of $\mathrm{N}_{2} \mathrm{O}$ emissions from drained and 
undrained cropped plots are scarce, but those that are available suggest contrasting effects of drainage, with larger emissions in undrained soils in dry periods but smaller emissions in wet periods (Venterea et al., 2008; Colbourn and Harper, 1987). Thus, drainage may have contrasting effects on local $\mathrm{N}_{2} \mathrm{O}$ emissions from soils depending on climatic conditions and the hydric history of the soils, and it is important to assess these overall effects.

Determining controls on soil $\mathrm{N}_{2} \mathrm{O}$ emissions is often difficult in field studies because of the many factors involved and the complex interactions between these factors. $\mathrm{N}_{2} \mathrm{O}$ production, at the microsite scale, is controlled by nitrogen, carbon substrates and oxygen availability, soil temperature and $\mathrm{pH}$ (Stehfest and Bouwman, 2006; Saggar et al., 2013). At larger scales, $\mathrm{N}_{2} \mathrm{O}$ emissions depend on distal factors (Williams et al., 1992) that influence the local factors, such as soil type (Van Groenigen et al., 2004), top soil texture (Skiba and Ball, 2002; Stehfest and Bouwman, 2006), topographic attributes (Vilain et al., 2010) and soil drainage class (Bouwman et al., 2002). Thus, ideally, it is necessary to assess the influence of the climate, crop management and soil factors to distinguish the effect of a single factor. Drainage may interact with other distal factors, especially because it deeply modifies soil hydrodynamics and a comprehensive understanding of the control of $\mathrm{N}_{2} \mathrm{O}$ emissions in both drained and undrained situations may be useful for proposing strategies to mitigate the emissions of greenhouse gases.

Moreover, drainage can also have an effect at larger scales because of possible nitrogen $(\mathrm{N})$ transfer by water. Drainage accelerates water discharge, and this water may entrain nitrate and dissolved $\mathrm{N}_{2} \mathrm{O}$, i.e., there could be pollution swapping with an increase of indirect $\mathrm{N}_{2} \mathrm{O}$ emissions from surface water. Large $\mathrm{N}_{2} \mathrm{O}$ emissions have been measured in drainage water (Reay et al., 2009; Beaulieu et al., 2009) and several processes have been identified to explain these indirect emissions: leaching of dissolved $\mathrm{N}_{2} \mathrm{O}$ produced in subsoil by denitrification (Reay et al., 2009), or leaching of nitrate followed by direct $\mathrm{N}_{2} \mathrm{O}$ production via denitrification in surface water, such as drainage ditches, streams and rivers in agriculture landscapes (Beaulieu et al., 2009; Boehlke et al., 2009; Garnier et al., 2010). Compared to direct $\mathrm{N}_{2} \mathrm{O}$ emissions, the relative importance of indirect $\mathrm{N}_{2} \mathrm{O}$ emissions from streams is still very uncertain; while some studies report that they represent a small fraction of the total $\mathrm{N}_{2} \mathrm{O}$ emissions (Reay et al., 2009; Vilain et al., 2012), they may also contribute significantly in other regions (Outram and Hiscock, 2012). In a recent study, Turner et al. (2015) showed that indirect $\mathrm{N}_{2} \mathrm{O}$ emissions represented $32 \%$ of the total $\mathrm{N}_{2} \mathrm{O}$ emission in the US Corn Belt and that headwater streams dominated this indirect contribution (60\%). This study also highlighted the severe lack of information on $\mathrm{N}_{2} \mathrm{O}$ emissions from non-permanent water flows, such as small drainage channels; taking these sources into account may double the total $\mathrm{N}_{2} \mathrm{O}$ emissions when compared to the estimations obtained from applying the standard Tier I IPCC methodology, which relies on a constant proportion of nitrogen supply emitted as $\mathrm{N}_{2} \mathrm{O}$ (Turner et al., 2015). This points to the need for new measurements in large agricultural areas around the world. Thus, assessing the overall impact of artificial drainage on $\mathrm{N}_{2} \mathrm{O}$ emissions requires determining whether drainage enhances indirect emissions. At present, answering this question is extremely complex: dissolved $\mathrm{N}_{2} \mathrm{O}$ measured in underground monitoring wells may further react before discharge depending on the residence time of underground water and the speed of denitrification (Well and Butterbach-Bahl, 2010), and estimating emissions from dissolved $\mathrm{N}_{2} \mathrm{O}$ in drainage water and gas exchange models can lead to an underestimation of emissions (Turner et al., 2015). Last, as water from field drains is generally conducted to collectors before reaching the atmosphere, this integrates $\mathrm{N}_{2} \mathrm{O}$ emissions from large surfaces and requires assessments at the landscape scale.
The objective of this work was to study the effect of artificial drainage on direct and indirect $\mathrm{N}_{2} \mathrm{O}$ emission from soils within a small agricultural region $\left(\sim 20 \mathrm{~km}^{2}\right)$ with naturally hydromorphic soils (Gu et al., 2011, 2013). Two questions were assessed. First, the influence of drainage as well as ancillary variables (climate conditions, soils properties) on direct $\mathrm{N}_{2} \mathrm{O}$ emissions was assessed by comparing the $\mathrm{N}_{2} \mathrm{O}$ emissions in drained and undrained plots. Second, as drainage is extensively used in the studied region, the indirect $\mathrm{N}_{2} \mathrm{O}$ emissions from the non-permanent stream that drains this region were investigated to evaluate the potential for pollution swapping induced by drainage and to assess the indirect $\mathrm{N}_{2} \mathrm{O}$ emissions as a proportion of the total $\mathrm{N}_{2} \mathrm{O}$ emissions.

\section{Materials and methods}

\subsection{Study site}

The study was carried out within an experimental site $\left(48^{\circ} 23^{\prime} \mathrm{N}\right.$, $1^{\circ} 11^{\prime} \mathrm{E}$; elevation $202 \mathrm{~m}$ a.s.l) in the Loir River valley, approximately $120 \mathrm{~km}$ southwest of Paris, France. The climate records (1971$2000)$ in the closest meteorological station in Chartres $\left(48^{\circ} 270^{\prime} \mathrm{N}\right.$, $1^{\circ} 300^{\prime}$ E, elevation $155 \mathrm{~m}$ a.s.l.) showed a mean annual temperature of $10.6^{\circ} \mathrm{C}$, precipitation of $598 \mathrm{~mm}$ and potential evaporation of $740 \mathrm{~mm}$. The study area $\left(20 \mathrm{~km}^{2}\right)$ is cultivated by commercial farms (not for scientific goals) and dominated by winter wheat (Triticum aestivum), barley (Hordeum vulgare) and rapeseed (Brassica napus) crops. The soils are LUVISOLS (WRB, 2015) with a loamy texture and poor natural drainage. However, tile-pipes have been installed in most fields to attenuate soil hydromorphy. Streams and main drainage ditches represent only a small surface of the studied site (approximately $0.1 \%$ ). Measurements of the direct $\mathrm{N}_{2} \mathrm{O}$ emissions were made during two growing seasons, from seeding to harvest (typically Nov-July), in 2010-2011 and in 2012-2013. The direct $\mathrm{N}_{2} \mathrm{O}$ emissions were measured on two undrained plots (referred to as ND) and two drained plots (referred to as D) during these two periods. ND plots were situated at the shoulder and the footslope of a very gently sloping field (slope $1.6 \%$ ) at a $208 \mathrm{~m}$ distance from each other. As climatic conditions are considered an influencing factor for $\mathrm{N}_{2} \mathrm{O}$ emissions, these two replicates will be hereafter referred to as ND1 (shoulder) and ND2 (footslope) in 2010-2011 and ND3 (shoulder) and ND4 (footslope) in 2012-2013 (Fig. 1). To maintain the same management practices as for the ND plots, the locations of the D plots were changed from the first year (referred as D1 and D2) to the second year (referred as D3 and D4). This is because the studied plots were managed by commercial farms, and crop management for D1 and D2 was not to the same as that of ND1 and ND2 during the second growing period. The crops were winter barley in 2010-2011 (total fertilization $140 \mathrm{~kg} \mathrm{~N} \mathrm{ha}^{-1}$ during spring in D1, D2, ND1 and ND2) and winter wheat in 2012-2013 (total fertilization $166 \mathrm{~kg} \mathrm{~N} \mathrm{ha}^{-1}$ in D3, D4, ND3 and ND4). All plots were tilled down to $30 \mathrm{~cm}$ depth with burial of previous crop residues. Details on the management practices are included in the supplementary material.

The experimental site was very close to the Loir headwater, where the stream is still non-permanent. The indirect $\mathrm{N}_{2} \mathrm{O}$ emissions from the surface water were thus measured during the flow periods (Nov-May) during the second growing season 2012-2013. The water drained from the D3 and D4 plots was routed to a main under-ground pipe reaching the surface at a distance of $1 \mathrm{~km}$ from the field where the collector discharged into a drainage ditch connecting to the Loir stream. To determine appropriate sites for the indirect $\mathrm{N}_{2} \mathrm{O}$ measurements, prospective measurements were made at a few dates in the drainage ditches and in the Loir stream channel (acting itself as a drainage ditch). The drainage ditches and the stream channel showed very similar $\mathrm{N}_{2} \mathrm{O}$ emissions. Thus, measurements were finally made at two 


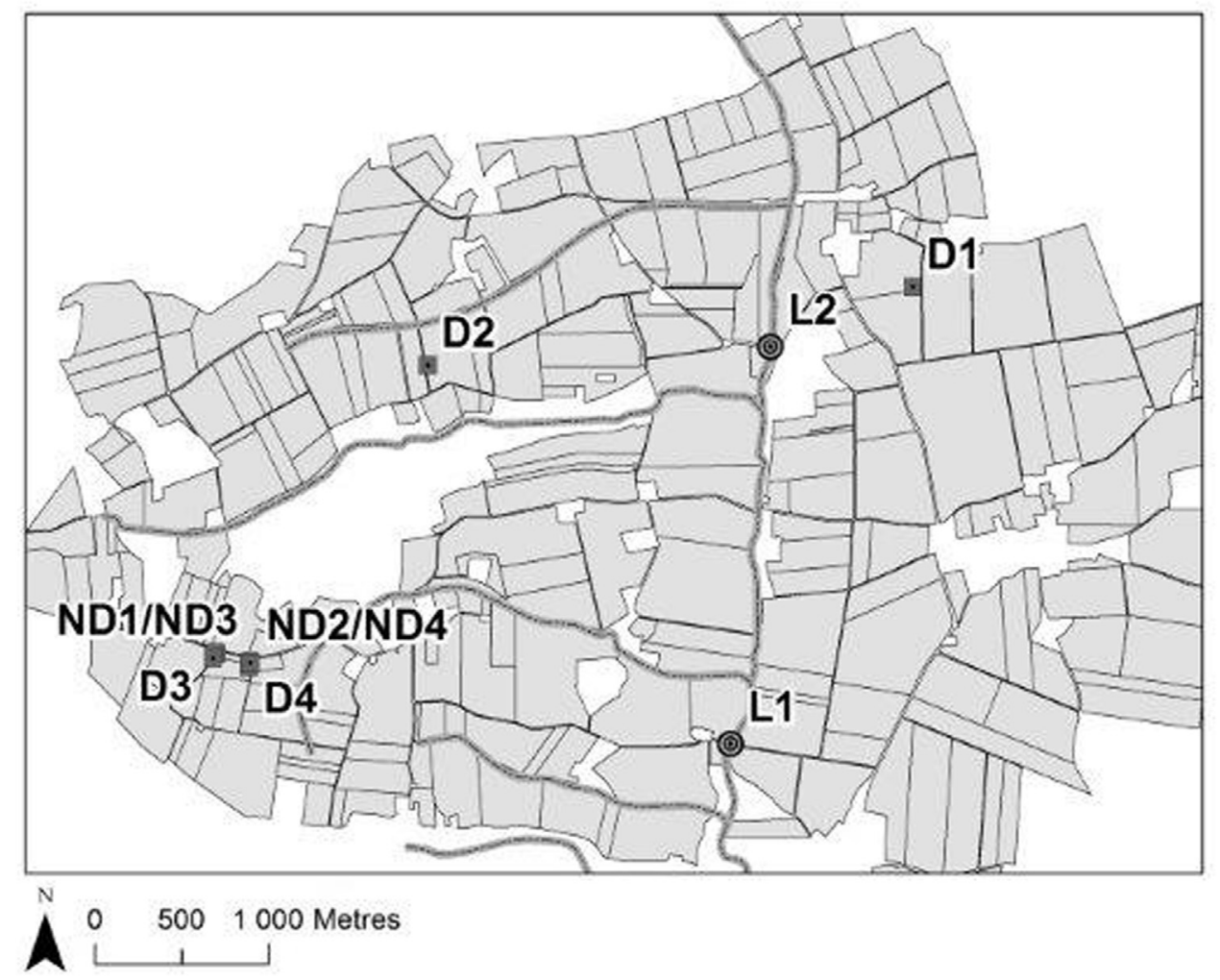

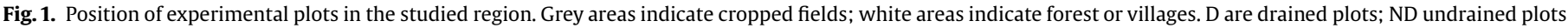
and L stream positions. ND1/ND3 and ND2/ND4 are situated on the same field but correspond to 2 different years (see Section 2.1 for details).

positions on the Loir stream channel, upstream and downstream of the site (Fig. 1), referred as L1 and L2, respectively.

\subsection{Measurements of $\mathrm{N}_{2} \mathrm{O}$ emissions}

Direct $\mathrm{N}_{2} \mathrm{O}$ emissions were measured with five static chambers per plot. Uncertainty was given by the standard error on these 5 replicates. During the first growing season (2010-2011), a nonflow through non-steady state method was used (Rochette and Bertrand, 2008). Sampling frequency was generally weekly, except in Oct-Dec 2010 and June 2011, when it was monthly. Square stainless-steel frames $(50 \times 50 \times 25 \mathrm{~cm}$ height $)$ were inserted to $10 \mathrm{~cm}$ depth into the soil at least two days before the first sampling date and remained until the end of the growing season. The distance between two frames was always $>1 \mathrm{~m}$, and the maximum distance between two frames on one plot was $15 \mathrm{~m}$. During measurements, the chambers were tightly closed with a vented PVC cover insulated by rubber foam. Four samples of air headspace were taken: just after closure and after 10, 20 and $30 \mathrm{~min}$ of accumulation. In the late spring, a supplementary $50 \mathrm{~cm}$ high frame was used to allow for plant height. Air samples were then taken 0,50 and $100 \mathrm{~min}$ after closing the chambers because of the higher volume. At each measurement time, three replicate gas samples were drawn using a syringe $(20 \mathrm{~mL})$ and injected into preevacuated vials $(12 \mathrm{~mL})$. In each vial, $3 \mathrm{mg}$ of magnesium perchlorate was placed to absorb the water vapour. The concentrations of $\mathrm{N}_{2} \mathrm{O}$ were analysed in the laboratory within two weeks of sampling using a gas chromatograph (Model 3800, Varian Inc., Walnut Creek, CA, USA) equipped with an electron capture detector (GC-ECD) and a headspace auto-injector (Combi Pal, CTC Analytics, Zurich, $\mathrm{CH}$ ). $\mathrm{N}_{2} \mathrm{O}$ fluxes are calculated following $\mathrm{Gu}$ et al. (2011) and Rochette and Bertrand (2008).

During the second year, a new instrument (QCL spectrometer) was available for gas analysis, enabling an on-line analysis with a higher sensitivity. This analyser is a laboratory-built instrument called SPIRIT (Robert, 2007; Guimbaud et al., 2011; Gogo et al., 2011). It was equipped for this study with a laser emitting between 2238.85 and $2239.20 \mathrm{~cm}^{-1}$ giving a standard deviation on a signal of $0.15 \mathrm{ppb}$ for $\mathrm{N}_{2} \mathrm{O}$ at $0.7 \mathrm{~Hz}$. A cover was adapted on top of the static chambers to recirculate air from the chamber headspace to the SPIRIT analyser and back to the chamber headspace with PTFE tubing (1/4-in. diameter). The air flow inside the headspace was not high enough to avoid air stratification, so the cover was equipped with a fan (SUNON KD 1209 PTS 3, size $90 \times 90 \mathrm{~mm}$, $2500 \mathrm{rpm}$ under $12 \mathrm{~V}$ ). The fan was powered under low voltage and provided a slow mixing of air in the chamber to avoid pressure disturbance on the soil surface. The high sensitivity of the SPIRIT analyser enabled measurements 3 min after the chamber closing. Once again, supplementary frames of 15 then $50 \mathrm{~cm}$ height were used when the plants grew higher with a longer accumulation time ( 4 then $5 \mathrm{~min}$ ). A preliminary test was conducted on 10 chambers to ensure that results obtained with the QCL spectrometer were consistent with the previously used method, i.e., the analysis of gas samples by GC-ECD in the lab (Grossel et al., 2014). The higher temporal resolution of the SIRIT analyser permitted a larger number of concentration measurements, so the concentration increase could be fitted by the HMR model to account for possible non-linear effects (Pedersen et al., 2010). In this study, the HMR non-linear model was applied to $11 \%$ of the cases, that is, only when it provided a better fit of the observed increase of concentration, most likely because the linear model is appropriate enough for very short time of gas accumulation.

The SPIRIT analyser also enabled indirect $\mathrm{N}_{2} \mathrm{O}$ flux measurements on the Loir stream. Indirect $\mathrm{N}_{2} \mathrm{O}$ emissions are generally derived from dissolved $\mathrm{N}_{2} \mathrm{O}$ measurements in the water flow coupled to simple gas exchange models, but the actual gas exchange depends on flow velocity; this method leads to underestimation (Turner et al., 2015). Direct measurements by 
drifting box were not possible in this study due to the small stream width and the frequent presence of vegetation. We thus coupled the SPIRIT analyser to a non-drifting box to provide indirect $\mathrm{N}_{2} \mathrm{O}$ emission measurements. The floating chamber was a $35 \mathrm{~cm}$ diameter Plexiglas cylinder of $12.5 \mathrm{~cm}$ height. It was equipped with a vent; the chamber was carefully placed over water before vent closure to avoid any pressure disturbance. Measurements were made with the same methodology used over soils: a slow mixing of air was made by a fan and the $\mathrm{N}_{2} \mathrm{O}$ accumulation in the headspace was measured during $4 \mathrm{~min}$. Five flux measurements were carried out along a stream cross-section at positions L1 and L2, and the mean flux was estimated as the average of the single fluxes. Nevertheless, as the stream is temporary, flow properties are extremely variable in time. At L1, the stream is channelled in a $4.35 \mathrm{~m}$ corridor under a bridge. The flow was measured at a few dates and was typically $0.2-0.6 \mathrm{~m} \mathrm{~s}^{-1}$. At $\mathrm{L} 2$, the streambed is natural (1-5 $\mathrm{m}$ width) with a very low flow at the edges (typically $0.1 \mathrm{~m} \mathrm{~s}^{-1}$ ) and riffles in the middle. The dissolved nitrate concentration was measured at all sampling dates and varied from 4.6 to $12.2 \mathrm{mg} \mathrm{N} \mathrm{L}^{-1}$ (mean $8.6 \mathrm{mg} \mathrm{N} \mathrm{L}^{-1}$ ) at L1 and from 4.4 to $9.0 \mathrm{mg} \mathrm{NL}^{-1}$ (mean $6.8 \mathrm{mg} \mathrm{N}^{-1}$ ) at L2. The stream width was measured at a few dates over 6 sections along the stream between $\mathrm{L} 1$ and $\mathrm{L} 2$ and varied from 1.0 to $4.5 \mathrm{~m}$; the median $(2.95 \mathrm{~m})$ was taken as representative of the stream width. The stream depth varied from 6 to $30 \mathrm{~cm}$ but was observed at more than $1.3 \mathrm{~m}$ during a flooding event. The mean water $\mathrm{pH}$ was 7.8 and the mean oxydoreduction potential was $452 \mathrm{mV}$.

\subsection{Ancillary variables}

The climate and soil properties were also measured to assess possible controls on the $\mathrm{N}_{2} \mathrm{O}$ emissions. The precipitation and air temperature were monitored using an automatic weather station (Campbell Scientific Ltd., Shepshed, UK). The volumetric water content and temperature were measured at the middle of the tilled layer $(15 \mathrm{~cm})$ close to each static chamber at the time of flux measurement. For each plot, twelve undisturbed soil cores were sampled using $9 \mathrm{~cm}$ diameter cylinders ( $0.5 \mathrm{~L}$ ) over the $0-10,10-20$ and $20-30 \mathrm{~cm}$ soil layers to measure the soil bulk density. All plots except D1 were also equipped with moisture probes (TDR CS616, Campbell Scientific) and thermocouple sensors (TC Direct, UK) placed horizontally at the middle of each layer, i.e., 5, 15 and $25 \mathrm{~cm}$ deep (three replicates per depth) to record the volumetric water content and temperature at a $2 \mathrm{~h}$ time step. The gravimetric soil water contents were determined every 3 weeks in 2011-2012 and at each sampling date in 2012-2013 on the 0-10, 10-20 and 20$30 \mathrm{~cm}$ soil layers to calibrate the TDR probes. A $60 \mathrm{~cm}$ deep piezometer was installed in the ND1, ND2, D3, ND3, D4 and ND4 plots to measure the water table level at a $2 \mathrm{~h}$ time step.

Moreover, three composite samples were made from six soil samples collected from each plot in two soil layers (0-10 and $10-30 \mathrm{~cm}$ ) to determine the mineral $\mathrm{N}$ contents. Fresh soils were extracted with a $\mathrm{KCl}$ solution $(0.5 \mathrm{M})$ and the $\mathrm{NH}_{4}{ }^{+}$and $\mathrm{NO}_{3}{ }^{-}$ contents were determined using an automated discrete photometric analyser (Aquakem 600, Thermo Fisher Scientific Inc., USA).

The soil texture (clay, silt and sand contents), soil organic carbon, total $\mathrm{N}$ contents (after dry combustion at $1000^{\circ} \mathrm{C}$ ) and $\mathrm{pH}$ in water were measured from the soil samples taken in the $0-20 \mathrm{~cm}$ layer in each chamber frame at the end of the measurement campaign. The samples were dried at room temperature, crushed and sieved with a $2 \mathrm{~mm}$ mesh, and analysed at LAS (Soil Analysis Laboratory, France). The soil type was identified by a profile examination.

\subsection{Data analysis}

Statistical data analysis was conducted with $\mathrm{R}$ ( $\mathrm{R}$ Core Team, 2014). The $\mathrm{N}_{2} \mathrm{O}$ measurements of every chamber are referred to as $\mathrm{N}_{2} \mathrm{O}$ fluxes, and the average of the fluxes per date was used to estimate the mean plot emission. The difference between the $\mathrm{N}_{2} \mathrm{O}$ emissions by the drained and undrained soils was tested by applying a non-parametric test (Mann-Whitney at level $\mathrm{p}<0.05$ ) to the $\mathrm{N}_{2} \mathrm{O}$ fluxes from all chambers and all dates because the frequency distributions were highly asymmetric, resulting in a non-normal distribution (Shapiro-Wilk test, $\mathrm{p}<0.001$ ). The skewness coefficient was 13.1 for all flux data and ranged from 1.8 (D4) to 5.8 (ND3).

To examine possible controls of the environmental covariates on the $\mathrm{N}_{2} \mathrm{O}$ emissions by the soils, a rule-based regression model was fitted to the $\mathrm{N}_{2} \mathrm{O}$ fluxes using the R Cubist package (Kuhn et al., 2014). Cubist is based on the tree-model algorithm M5 developed by Quinlan (1992) and deals simultaneously with quantitative and

Table 1

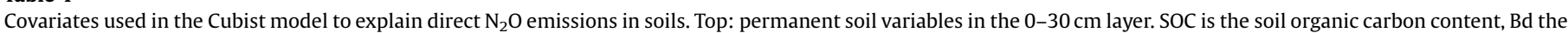

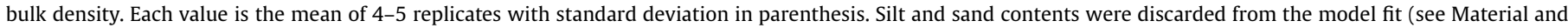
Method). Bottom: non-permanent variables; mean of 78-102 values including spatial and temporal replicates. See text for details.

\begin{tabular}{|c|c|c|c|c|c|c|c|c|}
\hline Plot & Clay (\%) & Silt (\%) & Sand (\%) & $\mathrm{SOC}\left(\mathrm{g} \mathrm{C} \mathrm{kg}^{-1}\right)$ & $\mathrm{Bd}\left(\mathrm{g} \mathrm{cm}^{-3}\right)$ & $\mathrm{pH}-\mathrm{H}_{2} \mathrm{O}$ & Soil type & Topography \\
\hline D1 & $17.3(0.3)$ & $78.1(0.2)$ & $4.6(0.2)$ & $10.4(0.6)$ & $1.36(0.02)$ & $6.4(0.3)$ & Luvisol & Shoulder \\
\hline D2 & $13.7(0.7)$ & $82.0(0.7)$ & $4.5(0.4)$ & $9.9(0.4)$ & $1.32(0.04)$ & $6.6(0.2)$ & Albeluvisol & Shoulder \\
\hline D3 & $17.0(0.6)$ & $78.2(0.5)$ & $4.8(0.5)$ & $8.1(0.5)$ & $1.41(0.06)$ & $8.1(0.1)$ & Albeluvisol & Shoulder \\
\hline D4 & $13.0(0.2)$ & $82.3(1.0)$ & $3.8(0.5)$ & $9.1(0.3)$ & $1.38(0.08)$ & $8.1(0.1)$ & Colluvic Cambisol & Footslope \\
\hline ND1 & $16.7(1.0)$ & $77.3(1.6)$ & $6.0(0.9)$ & $9.4(0.5)$ & $1.33(0.05)$ & $5.9(0.2)$ & Albeluvisol & Shoulder \\
\hline ND2 & $13.5(0.4)$ & $82.4(0.6)$ & $4.3(0.3)$ & $10.3(0.9)$ & $1.32(0.04)$ & $6.3(0.1)$ & Colluvic Cambisol & Footslope \\
\hline ND3 & $16.3(0.8)$ & $77.6(1.5)$ & $6.1(0.7)$ & $8.1(0.6)$ & $1.50(0.04)$ & $5.9(0.1)$ & Albeluvisol & Shoulder \\
\hline ND4 & $13.2(0.5)$ & $82.6(0.6)$ & $4.2(0.4)$ & $10.0(0.4)$ & $1.37(0.09)$ & $6.4(0.1)$ & Colluvic Cambisol & Footslope \\
\hline Plot & Crop & WFPS (\%) & \multicolumn{2}{|r|}{$\mathrm{T}\left({ }^{\circ} \mathrm{C}\right)$} & $\left(\mathrm{NO}_{3}{ }^{-}\right)\left(\mathrm{mg} \mathrm{N} \mathrm{kg}^{-1}\right)$ & \multicolumn{2}{|c|}{$\left(\mathrm{NH}_{4}^{+}\right)\left(\mathrm{mg} \mathrm{N} \mathrm{kg}^{-1}\right)$} & Precipitations $(\mathrm{mm})$ \\
\hline D1 & Barley & $49.2(23.2)$ & \multicolumn{2}{|r|}{$8.4(3.5)$} & $3.7(3.0)$ & \multicolumn{2}{|l|}{$2.3(2.1)$} & $3.8(6.6)$ \\
\hline D2 & Barley & $47.2(20.9)$ & & & $3.6(2.7)$ & \multicolumn{2}{|l|}{$2.6(2.0)$} & $3.8(6.6)$ \\
\hline D3 & Wheat & $75.9(7.1)$ & \multicolumn{2}{|r|}{$6.2(4.1)$} & $7.4(5.0)$ & \multicolumn{2}{|l|}{$1.9(1.9)$} & $14.6(15.9)$ \\
\hline D4 & Wheat & $73.14(6.3)$ & \multicolumn{2}{|r|}{$6.2(4.0)$} & $10.5(8.8)$ & $4.2(7.3)$ & & $14.6(15.9)$ \\
\hline ND1 & Barley & $55.3(24.4)$ & & $9.7(4.2)$ & $4.3(4.1)$ & $5.9(6.0)$ & & $3.8(6.6)$ \\
\hline ND2 & Barley & $61.7(29.1)$ & & $9.6(4.0)$ & $6.5(7.1)$ & $8.9(10.1)$ & & $3.8(6.6)$ \\
\hline ND3 & Wheat & $84.0(9.0)$ & & $6.7(4.7)$ & $4.4(2.9)$ & $3.0(3.0)$ & & $14.6(15.9)$ \\
\hline ND4 & Wheat & $83.0(9.6)$ & & $6.6(4.2)$ & $5.0(3.6)$ & $3.4(3.4)$ & & $14.6(15.9)$ \\
\hline
\end{tabular}


qualitative covariates. This algorithm splits the dataset into subsets, following decision rules in the IF-THEN form (namely condition rules) based on the environmental covariates (Kuhn and Johnson, 2013). Within each subset, an ordinary least-squares regression is applied to define a linear regression between the $\mathrm{N}_{2} \mathrm{O}$ fluxes and selected covariates (namely regression rules). The $\mathrm{N}_{2} \mathrm{O}$ emissions present the non-linear and non-additive influence of the control variables (Schmidt et al., 2000). Thus, the data split between the subdomains enables the approximation of linear rules, and the objective here is not to use the fitted model as a predictive tool but to discriminate the relative importance of the control factors. For this purpose, Cubist provides an explicit model enabling an easy interpretation of predictor importance (Lacoste et al., 2014).

The covariates included qualitative attributes (crop, soil type, topographic position and drainage) and quantitative attributes (nitrate and ammonium content, soil temperature, WFPS, soil bulk density, carbon (C) content, clay, $\mathrm{pH}$ and cumulated precipitation over the 5 days preceding the day of measurement) that are described in Table 1 . All the soil covariates were averaged over the $0-30 \mathrm{~cm}$ soil layer. The data gaps in the soil covariates (WFPS, temperature) were replaced with the mean of the other replicates at each plot at the same date.

To identify possible specific control factors in different situations, Cubist models were fitted to the $\mathrm{N}_{2} \mathrm{O}$ flux (i) from the full dataset and (ii) from drained and undrained plots separately. Regression tree models can suffer from instability (Kuhn and Johnson, 2013), i.e., a small change in the calibration dataset may generate a very large change in the predicted rules. The models were first fit to all available $\mathrm{N}_{2} \mathrm{O}$ flux data. Then, each $\mathrm{N}_{2} \mathrm{O}$ flux dataset was split randomly between a training fraction (75\%) used for the model fit and an evaluation fraction (25\%). This procedure was repeated 100 times to check the stability of the predicted factor weight and to provide error estimation on the relative importance of the covariates.

The performance of the fitted Cubist models was assessed by considering several statistical indexes. The agreement between the measured and predicted data is characterized by the coefficient of determination $\left(R^{2}\right)$ :

$R^{2}=\frac{\sum_{i=1}^{n} y_{i}-\bar{x}}{\sum_{i=1}^{n} x_{i}-\bar{x}}$

The accuracy of prediction is given by the root mean square error (RMSE):

$R M S E=\sqrt{\frac{\sum_{i=1}^{n}\left(y_{i}-x_{i}\right)^{2}}{n}}$

and the bias is given by the mean absolute error $(M E)$ :

$M E=\frac{1}{n} \sum_{i=1}^{n}\left|y_{i}-x_{i}\right|$

where $n$ is the $\mathrm{N}_{2} \mathrm{O}$ flux number, $x_{i}$ is the one flux measurement, $y_{i}$ is the corresponding flux prediction, and $\bar{x}$ is the mean measured flux.

The indirect $\mathrm{N}_{2} \mathrm{O}$ emissions could not be studied using a rulebased regression model because the study scale was different. However, the direct and indirect $\mathrm{N}_{2} \mathrm{O}$ emissions were compared by assessing the total emissions over the high-water period of 2012-2013. The total soil emissions were estimated from a triangular integration on data points, assuming that the mean of the 5 fluxes in each plot is representative of the daily emission level. The uncertainty of cumulative emissions was estimated from triangular integration from the mean value plus/minus the uncertainty at each date. The investigation in main drainage

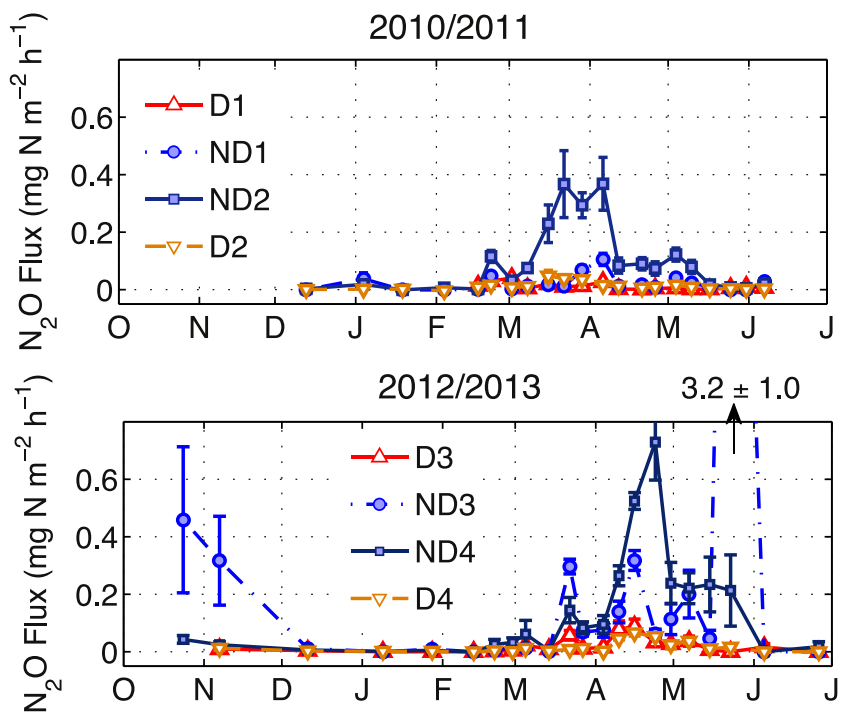

Fig. 2. $\mathrm{N}_{2} \mathrm{O}$ emissions from drained and undrained plots. Error bars show the standard error on 5 replicates. For the emission peak observed in ND3, the peak value is written with its associated error.

ditches at a few dates in the same area has shown the same magnitude of $\mathrm{N}_{2} \mathrm{O}$ emissions as the Loir stream; thus, the measured emission was supposed to be representative of surface water emissions at the study site scale. The total water emissions were estimated by multiplying the length of the stream and main drainage channels in the study site by a median stream width of $2.95 \mathrm{~m}$ and a mean channel width of $0.5 \mathrm{~m}$. The area covered by surface water was estimated roughly to represent $0.1 \%$ of the whole study site.

\section{Results}

\subsection{Specific climatic conditions during experiments}

The two growing seasons benefitted from very different climatic conditions, the first one corresponding to a rather dry period and the second to a wet one. During the period of Oct 2010-Jan 2011, the cumulative precipitation was $252 \mathrm{~mm}$, whereas it reached $328 \mathrm{~mm}$ during Oct 2012-Jan 2013, i.e., 30\% more. During the period of Feb-May 2011, the cumulative precipitation was only $83 \mathrm{~mm}$ (50\% drier than the mean climatological record over 30 years in the region), whereas over the same period in 2013 , it was 3 times higher $(252 \mathrm{~mm})$.

\subsection{Direct $\mathrm{N}_{2} \mathrm{O}$ emissions}

\subsection{1. $\mathrm{N}_{2} \mathrm{O}$ emissions}

For every plot and the two studied periods, the $\mathrm{N}_{2} \mathrm{O}$ emissions were lower during the winter periods with emission peaks following fertilization events during spring in all plots (Fig. 2). These peak $\mathrm{N}_{2} \mathrm{O}$ emissions were much larger and lasted longer in the undrained plots than in the drained plots. Large $\mathrm{N}_{2} \mathrm{O}$ fluxes were also measured in autumn 2012 after tillage in the undrained soils (especially for ND3). A very large peak was also observed on the 23rd of May 2013 for the ND3 plots: the mean $\mathrm{N}_{2} \mathrm{O}$ emission was one order of magnitude larger than the mean peak flux level of the undrained plots.

$\mathrm{N}_{2} \mathrm{O}$ emissions were ten-fold smaller on the drained plots than on the undrained ones in both growing seasons ( $\mathrm{p} \leq 0.001$, Fig. 3 ). There was no significant difference $(p=0.24)$ between $\mathrm{N}_{2} \mathrm{O}$ emissions from the drained plots in 2011 (D1 and D2) and in 2013 (D3 and D4); neither was there a difference $(p=0.14)$ in the 

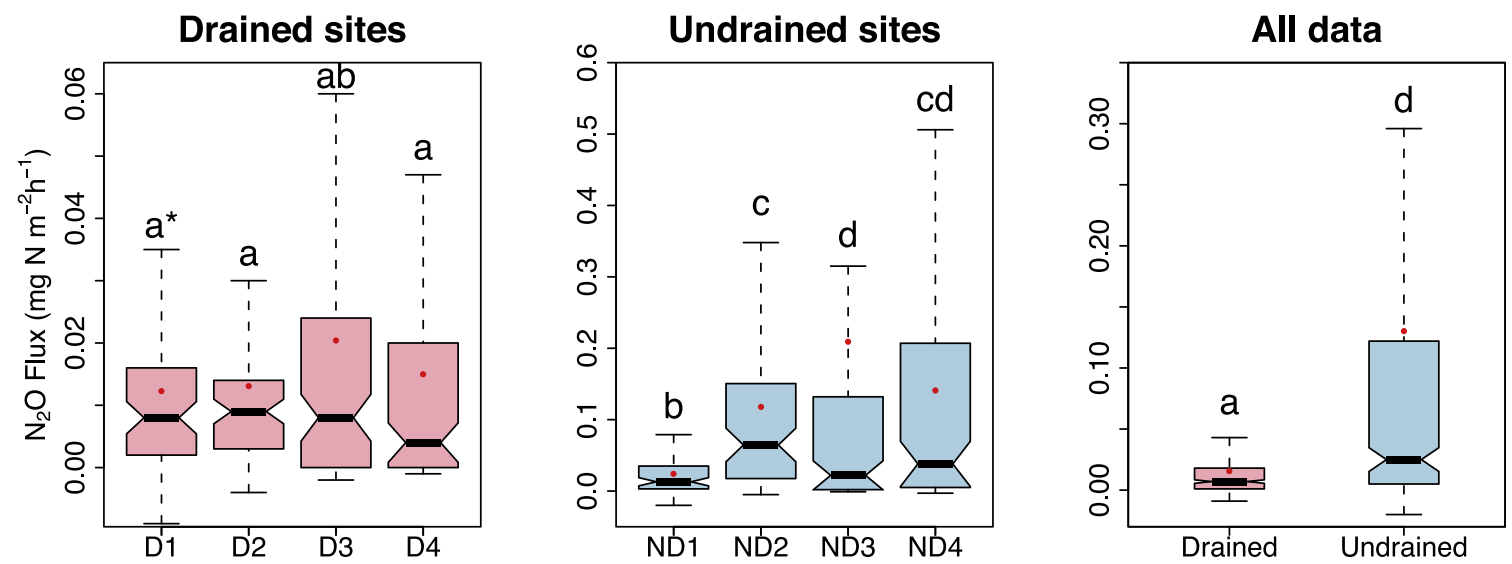

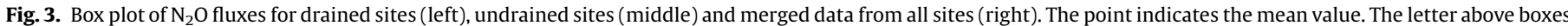
indicates whether flux distribution was significantly different at the 0.05 level with a Mann-Whitney test.

$\mathrm{N}_{2} \mathrm{O}$ emissions from the undrained plots in both years (ND1 and ND2 compared to ND3 and ND4). The variability between the undrained sites is larger than between the drained sites, and there were significant differences between the ND1, ND2 and both sites in 2013 (ND3 and ND4, Fig. 3, p < 0.05).

\subsubsection{Soil water status}

The soil WFPS was, on average, $9 \%$ higher in the undrained plots than in the drained ones (Fig. 4). The soils often reached saturation during winter in the undrained plots (especially ND2, ND3 and ND4) but never in the drained plots. The difference in WFPS between the drained and undrained situations was still visible at the end of the wet season 2012-2013. Similarly, a water table was measured at the surface at the ND2 plot in Feb. 2011 and at the ND3 and ND4 plots during long periods of the wet spring 2013 (Fig. 4). At the end of May 2013, a water table was again measured at the
ND3 plot after a heavy precipitation event $(56 \mathrm{~mm}$ rain from 17 th to 21th of May 2013), whereas no water table was observed above $60 \mathrm{~cm}$ at the other plots. Unexpectedly, a high water table level was observed over a long period in 2012-2013 at one of the drained plots (D3), suggesting that artificial drainage did not work efficiently while it was always able to decrease the surface WFPS.

\subsubsection{Influence of management, climate and soil variables on $\mathrm{N}_{2} \mathrm{O}$ emissions}

The fitted models resulted in a good $\mathrm{R}^{2}$ value but also a rather large inaccuracy with the RMSE equivalent to the mean flux value (Table 2). When a $25 \%$ bag fraction was considered, the evaluation of the models on it still gives a satisfactorily result. The performances of the fitted model for the data for the undrained condition were slightly better than the data for the drained condition (Table 2). The best result was obtained for the whole
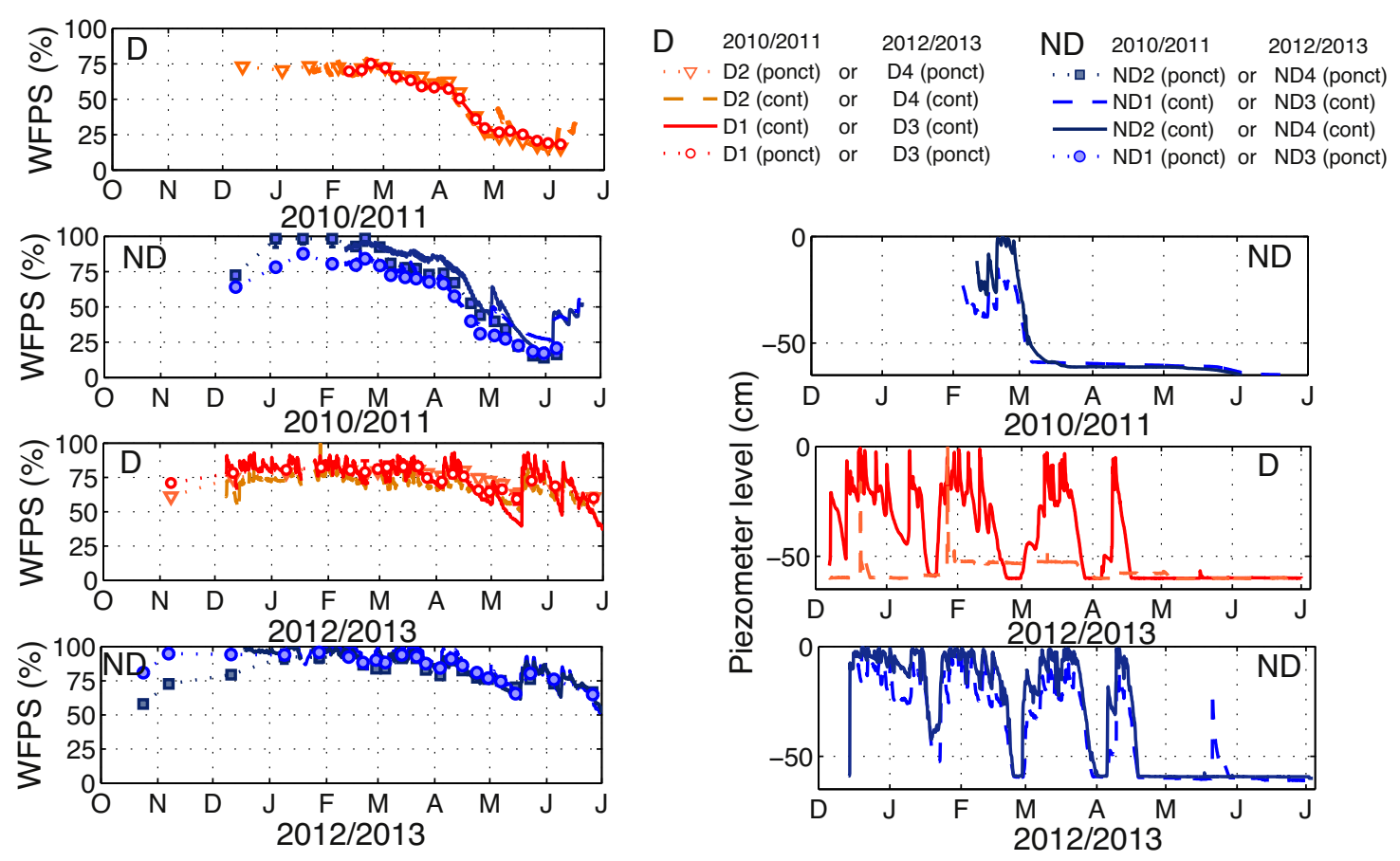

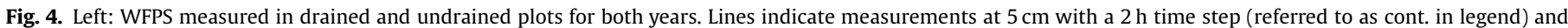

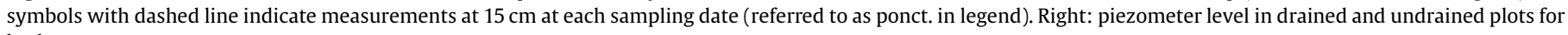
both years. 
Table 2

Performance of the fitted Cubist models for all data, drained data (D) and undrained data (ND). Mean error (ME), standard error (SDE) and root mean square error (RMSE) of predictions are in $\mathrm{mg} \mathrm{N} \mathrm{m}^{-2} \mathrm{~h}^{-1}$. Models were fitted first on all data, then on a training subset and the fitted model was evaluated on the remaining data (evaluation). See text for details.

\begin{tabular}{llrllll}
\hline Situation & & $\mathrm{n}$ & Rules number & $\mathrm{R}^{2}$ & $\mathrm{ME}$ & RMSE \\
\hline D and ND & All & 714 & 11 & 0.78 & -0.008 & 0.138 \\
& Training & 536 & - & 0.77 & -0.008 & 0.135 \\
& Evaluation & 178 & - & 0.63 & -0.013 & 0.197 \\
& & & & & & \\
$\mathrm{D}$ & All & 353 & 6 & 0.71 & -0.002 & 0.014 \\
& Training & 264 & - & 0.64 & -0.002 & 0.015 \\
& Evaluation & 89 & - & 0.40 & -0.003 & 0.020 \\
ND & & & & & \\
& All & 361 & 8 & 0.76 & -0.015 & 0.197 \\
& Training & 272 & - & 0.74 & -0.002 & 0.200 \\
& Evaluation & 89 & - & 0.59 & -0.010 & 0.287 \\
\hline
\end{tabular}

dataset ( $D$ and ND data) because the $R^{2}$ was larger on the validation dataset. This suggests that the more reliable factors have been identified in this case.

The rule-based model identified drainage as the main factor used in the condition rules (for $97 \%$ of the whole dataset; Fig. 5). This finding was stable: when only $75 \%$ of the dataset was randomly chosen for calibration, drainage was still identified in the condition rules in $83 \%$ of the cases. In the total model ( 11 rules), one rule included nearly all the data for the drained condition (345 over 353 ), and 9 rules were dedicated to the data for the undrained condition. The last rule is due to large precipitation events ( $>33 \mathrm{~mm}, 16 \mathrm{~N}_{2} \mathrm{O}$ flux data) in either the drained or undrained conditions (for the complete model description, see supplementary material) and uses ammonium content as the only variable in the regression. The crop, soil type and topographic attribute were not identified as possible control factors, even when the data from drained, and undrained plots were pooled separately. This may be due to correlation with other factors: for example, topographic attributes influence WFPS and soil nitrate content. Regression rules were mainly based on the nitrate content, temperature, WFPS and precipitation. Permanent soil variables such as $\mathrm{pH}$, clay and carbon (C) content have a smaller influence.

\subsection{Indirect $\mathrm{N}_{2} \mathrm{O}$ emissions from surface water}

The temporal variations of the $\mathrm{N}_{2} \mathrm{O}$ emissions emitted by the stream were different from those emitted by the soils (Figs. 2 and 5 ). High emissions were measured just after the stream began to flow in autumn and during high flow periods in winter and spring. Emissions were high during the whole experiment period and decreased at the end of flow period. The mean stream emission was $0.190 \mathrm{mg} \mathrm{N} \mathrm{m}^{-2} \mathrm{~h}^{-1}$ (ranging from 0.002 to $1.607 \mathrm{mg} \mathrm{N} \mathrm{m}^{-2} \mathrm{~h}^{-1}$ ) with non-significant differences between the $\mathrm{L} 1$ and $\mathrm{L} 2$ positions $(p>0.05)$. During the high-water period, the total Loir $\mathrm{N}_{2} \mathrm{O}$ emission per unit area was estimated to be $15.3 \pm 0.8 \mathrm{~kg} \mathrm{~N} \mathrm{ha}^{-1}$. For comparison, the total direct emission was $0.8 \pm 0.2 \mathrm{~kg} \mathrm{~N} \mathrm{ha}^{-1}$ for the drained soils and $4.9 \pm 0.3 \mathrm{~kg} \mathrm{~N} \mathrm{ha}^{-1}$ for the undrained soils during the same period.

\subsection{Comparison between direct and indirect $\mathrm{N}_{2} \mathrm{O}$ emission}

The $\mathrm{N}_{2} \mathrm{O}$ emissions from the stream were much larger than the direct $\mathrm{N}_{2} \mathrm{O}$ emissions on a per-unit-area basis. For comparison at the site scale, the mean emissions of the plots D3 and D4 were considered representative of drained (85.7\% of site surface) and non-hydromorphic soils ( $11.1 \%$ of site surface); the mean emissions of ND3 and ND4 was considered representative of undrained hydromorphic soils ( $3.2 \%$ of site surface). In this way, the indirect
$\mathrm{N} 20$ emissions were estimated at $31 \mathrm{~kg} \mathrm{~N}$ between mid-Oct and mid-May (flow period), and the soil emissions were estimated at $1846 \mathrm{~kg} \mathrm{~N}$, resulting in a fraction of $1.6 \%$ of the indirect emissions by the surface water compared to whole site emissions.

\section{Discussion}

The main objectives of this study were two-fold: (1) to compare the soil $\mathrm{N}_{2} \mathrm{O}$ emissions in drained and undrained plots and identify the main controls of emissions and (2) to compare the direct and indirect emissions in this drained landscape.

\subsection{Effect of drainage on direct $\mathrm{N}_{2} \mathrm{O}$ emissions}

\subsubsection{Effect of drainage, crop and soils properties}

The most important drivers found in the rule-based models (Fig. 5) were clearly drainage and nitrate content, followed by soil temperature and WFPS. These variables are well-known local factors controlling $\mathrm{N}_{2} \mathrm{O}$ production by soils (Hénault et al., 2005; Laville et al., 2011). These factors actually drive the temporal variation, both in time and intensity, of emissions following seasonal changes, precipitation and fertilization events. The $\mathrm{N}_{2} \mathrm{O}$ emission variability was larger in the undrained soils than in the drained ones, with higher inter-annual and inter-plot variability of the $\mathrm{N}_{2} \mathrm{O}$ emissions (Fig. 3). This lower $\mathrm{N}_{2} \mathrm{O}$ emission variability for the drained soils might be due to a lower heterogeneity in the soil hydromorphic conditions, linked to a drainage effect. The influence of ammonium content on the $\mathrm{N}_{2} \mathrm{O}$ emissions was much smaller, which suggests that nitrification played only a minor role in the $\mathrm{N}_{2} \mathrm{O}$ production at these sites, while denitrification may dominate.

Permanent soil variables can also be explanatory factors of the spatial variability of emissions (Stehfest and Bouwman, 2006). These variables were indeed used by the regression model, but their influence was smaller than the variables having a temporal dynamic. The clay content was identified as a stronger control factor in the undrained soils than in the drained ones, whereas a previous study conducted in the same region identified clay content as a control factor in the drained plots (Gu et al., 2013). The effect of $\mathrm{pH}$, soil $\mathrm{C}$ content and bulk density are either very small in the undrained soils or extremely unstable in the drained soils as shown by the large error bars in Fig. 5 , so no clear conclusions can be drawn from the present study.

Except for drainage, none of the qualitative variables (crop, soil type, topographic attribute) was identified by the model as a control factor. A previous study in this region showed no link between the topographic attributes and emissions in the drained soils (Gu et al., 2011), although other studies have reported larger water, carbon and nitrogen contents in soils, denitrification hotspots and larger $\mathrm{N}_{2} \mathrm{O}$ emissions in footslopes (Pennock et al., 1992; Vilain et al., 2010). The absence of topography effects in the drained soils in this region may be due to a decrease in runoff because of drainage and the gentle slope. So an effect may still be possible in the undrained plots. Emissions were indeed significantly larger in the undrained footslope in 2011 (ND1 < ND2, $\mathrm{p} \leq 0.001$ ) and between January and mid-May 2013 (ND3 < ND4, $\mathrm{p}=0.02$ ). The opposite was observed in the periods of heavy precipitations, with much larger emissions in the shoulder of ND3 (autumn 2012, 23rd of May 2013); a competing effect between topographic attributes and soil type may have taken place. Topographic attributes were likely not identified as controlling variables in the Cubist models both because of their opposite effects and also because it is a categorical variable with only 2 levels (shoulder/footslope). The Cubist method is less sensitive to categorical variables having very few levels (Kuhn and Johnson, 2013). Thus, these results do not show that topography is not an important factor to explain the $\mathrm{N}_{2} \mathrm{O}$ emissions but only show that 


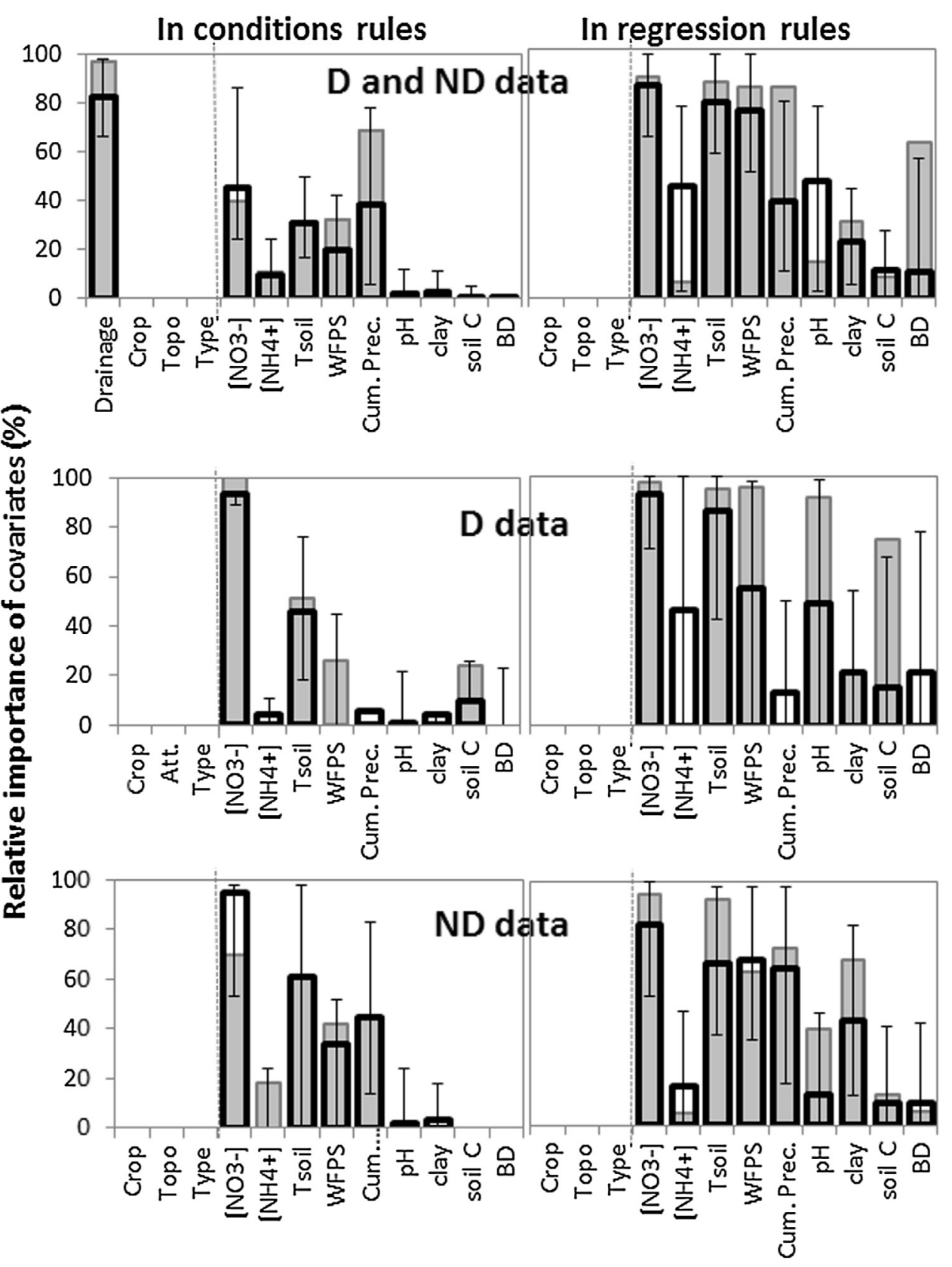

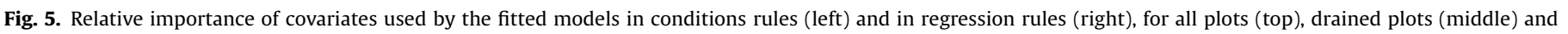

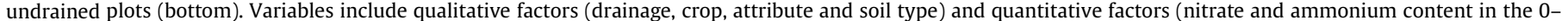

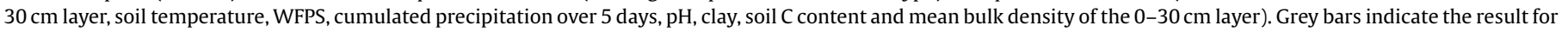

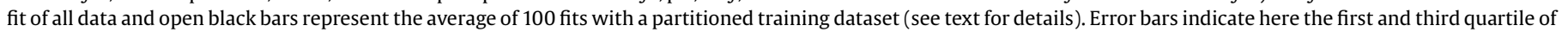
distributions.

the two-level topographic attribute used in the models should not be the most appropriate variable. Moreover, it is likely that the topography influences the soil water conditions, as well as the WFPS, which has been identified as an important factor controlling the $\mathrm{N}_{2} \mathrm{O}$ emissions. On the other hand, the drainage variable also had only 2 levels (drained/undrained) and was still identified clearly as a dominant control factor. This is not surprising because much larger $\mathrm{N}_{2} \mathrm{O}$ emissions were measured on the undrained plots on nearly all the sampling dates. This suggests that drainage was the dominant soil-controlling factor in this study, playing a role as important as very well-known factors, such as nitrate content. Thus, it would be important to also take it into account for inventories on larger areas and for the prediction of $\mathrm{N}_{2} \mathrm{O}$ emission by models.

\subsubsection{Effect of drainage and climatic conditions}

The a priori hypothesis was that the effect of drainage on the $\mathrm{N}_{2} \mathrm{O}$ emissions could be different depending on the climatic conditions because smaller $\mathrm{N}_{2} \mathrm{O}$ emissions are expected from saturated soils (Colbourn and Harper, 1987; Venterea et al., 2008). However, the $\mathrm{N}_{2} \mathrm{O}$ emissions were measured even in saturated soils in this study. The difference between emissions from the drained and undrained soils was also significant when considering the data from the two growing seasons together. The total $\mathrm{N}_{2} \mathrm{O}$ emissions were larger, although not significantly, in the wet spring of 2013 than in the dry spring of 2011. Thus, in this region and in the periods following fertilizations, the $\mathrm{N}_{2} \mathrm{O}$ emission levels from the undrained soils were larger than the emissions from the drained soils, both in wet and dry climatic conditions. 


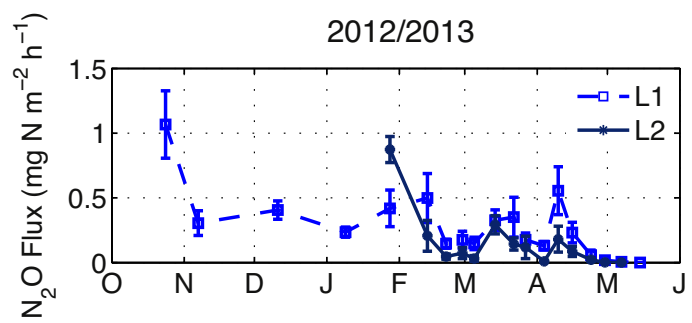

Fig. 6. $\mathrm{N}_{2} \mathrm{O}$ emissions in the Loir stream for positions L1 and L2. Sampling frequency varied from one to four times per month.

One interesting result found by using the rule-based models to identify the controls on $\mathrm{N}_{2} \mathrm{O}$ emissions was the importance of precipitation in the undrained plots but not in the drained ones (Fig. 6). Tiles can accelerate drainage of heavy precipitations and avoid soil saturation, thus decreasing the $\mathrm{N}_{2} \mathrm{O}$ production in anoxic situations. Heavy precipitation events occurred during the second period of the experiment, between 24th of Sept. and 23th of Oct. $2012(174 \mathrm{~mm})$ and between 17th and 21th of May 2013 (56 mm). The model that was fitted to all data used one rule to partition fluxes following a large amount of precipitation, independently of the presence of drainage. The regression rule in this case actually used only the ammonium content. Actually, large ammonium contents were measured in the undrained situations, likely due to mineralization flushes in opposition to the drained ones, especially on the 23rd of May 2013. At this date, the very large peak measured at ND3 likely corresponds to a rewetting event as reported in numerous studies (Barton et al., 2008; Zona et al., 2011; Kim et al., 2012). The very large peak may be explained by the higher soil bulk density, as compaction enhances emission pulse intensity after rewetting (Beare et al., 2009) and by the rising groundwater table, only observed at this plot (Fig. 2). Emissions were observed two days after the end of the rain, when the soil was draining, and the water table was receding. The release of soil gas can indeed occur as the air entry point is reached when drainage proceeds, whereupon maximum $\mathrm{N}_{2} \mathrm{O}$ fluxes occur with declining $\mathrm{N}_{2} \mathrm{O}$ emissions also occurring as $\mathrm{O}_{2}$ enters the soil due to drainage (Saggar et al., 2013; Balaine et al., 2013; Rabot et al., 2014). Thus, drainage may enable the effect of rewetting events to be reduced, which further amplifies the net effect of drainage on $\mathrm{N}_{2} \mathrm{O}$ emissions. This is important because rewetting events can represent a large part of the annual $\mathrm{N}_{2} \mathrm{O}$ budget (Goldberg et al., 2010).

\section{2. $\mathrm{N}_{2} \mathrm{O}$ emissions from the surface water}

The local decrease of direct $\mathrm{N}_{2} \mathrm{O}$ emissions due to drainage could be partly counteracted by an increase in the indirect $\mathrm{N}_{2} \mathrm{O}$ emissions. However, the fraction of indirect $\mathrm{N}_{2} \mathrm{O}$ emissions by the surface water compared to the whole site emissions is small (1.6\%). It is much smaller than the one observed by Turner et al. (2015) in a $7850 \mathrm{~km}^{2}$ area within the US Corn Belt (32\%), whereas the stream area was $0.16 \%$ of that site, which is similar to the present site $(0.1 \%)$. This might be because the mean indirect $\mathrm{N}_{2} \mathrm{O}$ emissions were one order of magnitude smaller in the present study than in the Turner study $\left(17.3 \mathrm{nmol} \mathrm{N}_{2} \mathrm{O} \mathrm{m}^{-2} \mathrm{~s}^{-1}\right.$, i.e., $1.74 \mathrm{mg} \mathrm{N} \mathrm{m}^{-2} \mathrm{~h}^{-1}$, against $0.190 \mathrm{mg} \mathrm{N} \mathrm{m}^{-2} \mathrm{~h}^{-1}$ for our study). Oppositely, the present result is very similar to the $1.8 \%$ ratio proposed by Vilain et al. (2012) in France. They estimated indirect $\mathrm{N}_{2} \mathrm{O}$ emissions of $0.035 \mathrm{~kg} \mathrm{Nha}^{-1}$ year $^{-1}$ when reported to the whole area of a $45.7 \mathrm{~km}^{2}$ watershed; in the present study, reporting indirect $\mathrm{N}_{2} \mathrm{O}$ emission to the site area $\left(19.41 \mathrm{~km}^{2}\right)$ gives $0.016 \mathrm{~kg} \mathrm{~N}^{-1} \mathrm{year}^{-1}$, which is smaller but comparable, because indirect emissions occur only during the flow period (mid. Oct. 2012 to mid. May 2013).
Turner et al. (2015) used a floating chamber and measured emissions from surface waters. Oppositely, Vilain et al. (2012) considered only the part of the indirect emission linked to underground waters and used measurements of underground dissolved nitrous oxide. The total indirect emission was estimated from the watershed discharge. The study scale, crops (cereals and beans) and climate in Vilain et al. (2012) were more similar to the present study than those of Turner et al. (2015). Thus, the present study suggests that indirect emissions from temporary streams in France is comparable to the emissions from underground water in a site with permanent streams.

Measuring $\mathrm{N}_{2} \mathrm{O}$ fluxes from a temporary stream is difficult and some limitations can be seen in the present method. Non-drifting chambers can enhance the water-atmosphere exchange and lead to flux overestimation. Moreover, the measurements were limited to one year, but the year was wetter than average, and the flow period was longer than usual ( 7 months instead of $4-5$ months, as is usually observed). These facts would actually reinforce the conclusion of the present study about the small influence of indirect emissions at the site scale.

Pollution swapping still cannot be ruled out on the current measurements. Secondary drainage ditches, where water flows only after precipitation events, were neglected in the budget and have to be verified. Large and temporally variable sources of $\mathrm{N}_{2} \mathrm{O}$ may exist at drain outlets (Reay et al., 2004). Moreover, high nitrate content is observed in the water in the present study and is directly exported. Nitrate may be denitrified in water sediments (Garnier et al., 2010) and an unknown amount of $\mathrm{N}_{2} \mathrm{O}$ may be emitted downstream from the experimental site. This has still to be assessed in future studies. Thus, there remains a need for further studies on indirect $\mathrm{N}_{2} \mathrm{O}$ emissions at several scales.

\section{Conclusion}

The first objective of this study was to assess the effect of artificial drainage on the $\mathrm{N}_{2} \mathrm{O}$ emissions from loamy soils. The undrained soils showed significantly larger emissions than drained soils during both dry and wet years. The net effect of artificial drainage may be a large decrease in the direct $\mathrm{N}_{2} \mathrm{O}$ emissions at this study site. A rule-based model was fitted to all flux data and clearly split fluxes between the drained and undrained situations. Drainage was the main factor explaining the spatial variability of the $\mathrm{N}_{2} \mathrm{O}$ emissions within the studied soils, and its effect was dominant over other permanent soil variables. This strongly suggests that drainage must be taken into account for $\mathrm{N}_{2} \mathrm{O}$ emission inventory.

As drainage could also induce pollution swapping by increasing indirect $\mathrm{N}_{2} \mathrm{O}$ emissions, the second objective of this study was to investigate the indirect $\mathrm{N}_{2} \mathrm{O}$ emissions from the surface water draining the site. The monitoring results suggested that $\mathrm{N}_{2} \mathrm{O}$ emissions from streams might represent only a small fraction of the total emissions (1.6\%). This finding requires further investigation in different sites because of the complexity of measurements involved in indirect $\mathrm{N}_{2} \mathrm{O}$ emissions from non-permanent streams.

\section{Acknowledgments}

We gratefully acknowledge Philippe Rochette and Bertrand Normand for their scientific and technical help in the first part of experiments; we acknowledge A. Ayzac, G. Giot, C. Pasquier, C. Lelay and P. Courtemanche for their technical assistance during field measurements and Pierre Cellier for his careful reading of the manuscript. This work was supported by the Région CENTRE, the Fonds Européen de Développement Régional (FEDER) and INRA through the SPATIOFLUX Project, the INDIGES project, and also by 
the Labex Voltaire (ANR-10-LABX-100-01) and the ANR Escapade project (ANR-12-AGRO-0003).

\section{Appendix A. Supplementary data}

Supplementary data associated with this article can be found, in the online version, at http://dx.doi.org/10.1016/j.agee.2016.06.015.

\section{References}

Balaine, N., Clough, T.J., Beare, M.H., Thomas, S.M., Meenken, E.D., Ross, J.G., 2013. Changes in relative gas diffusivity explain soil nitrous oxide flux dynamics. Soil Sci. Soc. Am. J. 77, 1496-1505. doi:http://dx.doi.org/10.2136/sssaj2013.04.0141.

Barton, L., Kiese, R., Gatter, D., Butterbach-Bahl, K., Buck, R., Hinz, C., Murphy, D.V., 2008. Nitrous oxide emissions from a cropped soil in a semi-arid climate. Global Change Biol. 14, 177-192.

Beare, M., Gregorich, E., St-Georges, P., 2009. Compaction effects on $\mathrm{CO}_{2}$ and $\mathrm{N}_{2} \mathrm{O}$ production during drying and rewetting of soil. Soil Biol. Biochem. 41, 611-621.

Beaulieu, J.J., Arango, C.P., Tank, J.L., 2009. The effects of season and agriculture on nitrous oxide production in headwater streams. J. Environ. Qual. 38, 637-646.

Boehlke, J.K., Antweiler, R.C., Harvey, J.W., Laursen, A.E., Smith, L.K., Smith, R.L., Voytek, M.A., 2009. Multi-scale measurements and modeling of denitrification in streams with varying flow and nitrate concentration in the upper Mississippi River basin, USA. Biogeochemistry 93, 117-141.

Bouwman, A.F., Boumans, L.J.M., Batjes, N.H., 2002. Emissions of $\mathrm{N}_{2} \mathrm{O}$ and NO from fertilized fields: summary of available measurement data. Global Biogeochem. Cycles 16, 1058

Bouwman, A.F., 1996. Direct emission of nitrous oxide from agricultural soils. Nutr. Cycl. Agroecosyst. 46, 53-70.

Castellano, M.J., Schmidt, J.P., Kaye, J.P., Walker, C., Graham, C.B., Lin, H., Dell, C.J., 2010. Hydrological and biogeochemical controls on the timing and magnitude of nitrous oxide flux across an agricultural landscape. Global Change Biol. 16, 2711-2720.

Colbourn, P., Harper, I.W., 1987. Denitrification in drained and undrained arable clay soil. J. Soil Sci. 38, 531-539.

Davidson, E.A., Verchot, L.V., 2000. Testing the hole-in-the-pipe model of nitric and nitrous oxide emissions from soils using the tragnet database. Global Biogeochem. Cycles 14, 1035-1043.

Dobbie, K.E., Smith, K.A., 2001. The effects of temperature, water-filled pore space and land use on $\mathrm{N}_{2} \mathrm{O}$ emissions from an imperfectly drained gleysol. Eur. J. Soil Sci. 52, 667-673.

Dobbie, K.E., Smith, K.A., 2006. The effect of water table depth on emissions of $\mathrm{N}_{2} \mathrm{O}$ from a grassland soil. Soil Use Manage. 22, 22-28.

Garnier, J.A., Mounier, E.M., Laverman, A.M., Billen, G.F., 2010. Potential denitrification and nitrous oxide production in the sediments of the Seine river drainage network (France). J. Environ. Qual. 39, 449-459.

Gogo, S., Guimbaud, C., Laggoun-Défarge, F., Catoire, V., Robert, C., 2011. In situ quantification of $\mathrm{CH}_{4}$ bubbling events from a peat soil using a new infrared laser spectrometer. J. Soils Sediments 11, 545-551.

Goldberg, S.D., Knorr, K.H., Blodau, C., Lischeid, G., Gebauer, G., 2010. Impact of altering the water table height of an acidic fen on $\mathrm{N}_{2} \mathrm{O}$ and NO fluxes and soil concentrations. Global Change Biol. 16, 220-233.

Grossel, A., Nicoullaud, B., Bourennane, H., Rochette, P., Guimbaud, C., Chartier, M., Catoire, V., Henault, H., 2014. Simulating the spatial variability of nitrous oxide emission from cropped soils at the within-field scale using the NOE model. Ecol. Model. 288, 155-165.

Gu, J., Nicoullaud, B., Rochette, P., Pennock, D.J., Hénault, C., Cellier, P., Richard, G., 2011. Effect of topography on nitrous oxide emissions from winter wheat fields in Central France. Environ. Pollut. 159, 3149-3155.

Gu, J., Nicoullaud, B., Rochette, P., Grossel, A., Hénault, C., Cellier, P., Richard, G., 2013. A regional experiment suggests that soil texture is a major control of $\mathrm{N}_{2} \mathrm{O}$ emissions from tile-drained winter wheat fields during the fertilization period. Soil Biol. Biochem. 60, 134-141.

Guimbaud, C., Catoire, V., Gogo, S., Robert, C., Chartier, M., Laggoun-Defarge, F., Grossel, A., Alberic, P., Pomathiod, L., Nicoullaud, B., Richard, G., 2011. A portable infrared laser spectrometer for flux measurements of trace gases at the geosphere-atmosphere interface. Meas. Sci. Technol. 22, 075601.

Hénault, C., Bizouard, F., Laville, B., Nicoullaud, B., Germon, J.C., Cellier, P., 2005. Predicting in situ $\mathrm{N}_{2} \mathrm{O}$ emission using NOE algorithm and soil database. Global Change Biol. 11, 115-127.

Jungkunst, H.F., Fielder, S., 2007. Latitudinal differentiated water table control of carbon dioxide, methane and nitrous oxide fluxes from hydromorphic soils: feedbacks to climate change. Global Change Biol. 13, 2668-2683.

Jungkunst, H.F., Freibauer, A., Neufeldt, H., Bareth, G., 2006. Nitrous oxide emissions from agricultural land use in Germany-a synthesis of available annual field data. J. Plant Nutr. Soil Sci. 169, 341-351.

Kim, D.G., Vargas, R., Bond-Lamberty, B., Turetsky, M.R., 2012. Effects of soil rewetting and thawing on soil gas fluxes: a review of current literature and suggestions for future research. Biogeosciences 9, 2459-2483.

Kuhn, M., Johnson, K., 2013. Regression trees and rule-based models. Applied Predictive Modeling. Springer, New York.
Kuhn, M., Weston, S., Keefer, C., Coulter, N., 2014. C code for Cubist by Ross Quinlan. Cubist: Rule- and Instance-Based Regression Modeling. R package version 0.0.18. http://CRAN.R-project.org/package=Cubist.

Lacoste, M., Minasny, B., McBratney, A., Michot, D., Viaud, V., Walter, C., 2014. High resolution $3 \mathrm{~d}$ mapping of soil organic carbon in a heterogeneous agricultural landscape. Geoderma 213, 296311.

Laville, P., Lehuger, S., Loubet, B., Chaumartin, F., Cellier, P., 2011. Effect of management, climate and soil conditions on $\mathrm{N}_{2} \mathrm{O}$ and $\mathrm{NO}$ emissions from an arable crop rotation using high temporal resolution measurements. Agric. For Meteorol. 151, 228-240.

Outram, F.N., Hiscock, K.M., 2012. Indirect nitrous oxide emissions from surface water bodies in a lowland arable catchment: a significant contribution to agricultural greenhouse gas budgets? Environ. Sci. Technol. 46, 8156-8163.

Pedersen, A.R., Petersen, S.O., Schelde, K., 2010. A comprehensive approach to soilatmosphere trace-gas flux estimation with static chambers. Eur. J. Soil Sci. 61 888-902.

Pennock, D.J., Van Kessel, C., Farrell, R.E., Sutherland, R.A., 1992. Landscape-scale variations in denitrification. Soil Sci. Soc. Am. J. 56, 770-776.

Quinlan,, 1992. Learning with continuous classes. Proceedings of the 5th Australian Joint Conference on Artificial Intelligence 343-348.

R Core Team, 2014. R: A Language and Environment for Statistical Computing. R Foundation for Statistical Computing, Vienna, Austria. http://www.R-project. org/.

Rabot, E., Hénault, C., Cousin, I., 2014. Temporal variability of nitrous oxide emissions by soils as affected by hydric history. Soil Sci. Soc. Am. J. 78, 434-444

Reay, D.S., Edwards, A.C., Smith, K.A., 2004. Determinants of nitrous oxide from agricultural drainage waters. Water Air Soil Pollut. 4, 107-115.

Reay, D.S., Edwards, A.C., Smith, K.A., 2009. Importance of indirect nitrous oxide emissions at the field, farm and catchment scale. Agric. Ecosyst. Environ. 133, 163-169.

Robert, C., 2007. Simple, stable, and compact multiple-reflection optical cell for verylong optical paths. Appl. Opt. 46, 5408-5418.

Rochette, P., Bertrand, N., 2008. Soil-surface gas emissions, In: Carter, M., Gregorich, E.G. (Eds.), Soil Sampling and Methods of Analysis. 2nd ed. CRC Press, Boca Raton, FL, pp. 851-861.

Saggar, S., Jha, N., Deslippe, J., Bolan, N.S., Luo, J., Giltrap, D.L., Kim, D., Zaman, M. Tillman, R.W., 2013. Denitrification and $\mathrm{N}_{2} \mathrm{O}: \mathrm{N}_{2}$ production in temperate grasslands: processes, measurements, modelling and mitigating negative impacts. Sci. Total Environ. 465, 173195.

Schmidt, U., Thoeni, H., Kaupenjohann, M., 2000. Using a boundary line approach to analyze $\mathrm{N}_{2} \mathrm{O}$ flux data from agricultural soils. Nutr. Cycl. Agroecosyst. 57, 119129.

Skiba, U., Ball, B., 2002. The effect of soil texture and soil drainage on emissions of nitric oxide and nitrous oxide. Soil Use Manage. 18, 56-60.

Smith, K.A., Ball, T., Conen, F., Dobbie, K.E., Massheder, J., Rey, A., 2003. Exchange of greenhouse gases between soil and atmosphere: interactions of soil physical factors and biological processes. Eur. J. Soil Sci. 54, 779-791.

Stehfest, E., Bouwman, L., 2006. $\mathrm{N}_{2} \mathrm{O}$ and NO emission from agricultural fields and soils under natural vegetation: summarizing available measurement data and modeling of global annual emissions. Nutr. Cycl. Agroecosyst. 74, 207-228.

Turner, P.A., Griffis, T.J., Lee, X., Baker, J.M., Venterea, R.T., Wood, J.D., 2015. Indirect nitrous oxide emissions fom streams within the US Corn Belt scale with stream ordre. Proc. Natl. Acad. Sci. 112, 9839-9843.

Van Groenigen, J.W., Kasper, G.J., Velthof, G.L., Van den Pol-van Dasselaar, A., Kuikman, P.J., 2004. Nitrous oxide emissions from silage maize fields under different mineral nitrogen fertilizer and slurry applications. Plant Soil 263,101111.

Venterea, R.T., Strock, J., Rosen, C., 2008. Agricultural management effects on nitrous oxide gas emissions. Proceedings of the Lamberton and Outreach Center Soil and Water Management Field Day.

Vilain, G., Garnier, J., Tallec, G., Cellier, P., 2010. Effect of slope position and land use on nitrous oxide emissions. Agric. For. Meteorol 150, 1192-1202.

Vilain, G., Garnier, J., Tallec, G., Tournebize, J., 2012. Indirect $\mathrm{N}_{2} \mathrm{O}$ emissions from shallow groundwater in an agricultural catchment (Seine Basin, France). Biogeochemistry 111, 253-271.

WRB, 2015. World Reference Base for Soil Resources 2014, update 2015. International soil classification system for naming soils and creating legends for soil maps. World Soil Ressources Reports No. 106. FAO, Rome.

Well, R., Butterbach-Bahl, K., 2010. Nitrous Oxide and Climate Change. Smith, Keith A. chapter 8. Indirect Emissions of Nitrous Oxide from Nitrogen deposition and Leaching of Agricultural Nitrogen.

Williams, E., Hutchinson, G., Fehsenfeld, F., 1992. NOx and $\mathrm{N}_{2} \mathrm{O}$ emissions from soils. Global Biogeochem. Cycles 6, 351-388.

Zona, D., Janssens, I.A., Verlinden, M.S., Broeckx, L.S., Cools, J., Gioli, B., Zaldei, A. Ceulemans, R., 2011. Impact of extreme precipitation and water table change on $\mathrm{N}_{2} \mathrm{O}$ fluxes in a bio-energy poplar plantation. Biogeosci. Discuss. 8, 2057-2092.

van Beek, C., Pleijter, M., Jacobs, C., Velthof, G., Groenigen, J., Kuikman, P., 2010. Emissions of $\mathrm{N}_{2} \mathrm{O}$ from fertilized and grazed grassland on organic soil in relation to groundwater level. Nutr. Cycl. Agroecosyst. 86, 331-340.

von Arnold, K., Weslien, P., Nilsson, M., Svensson, B., Klemedtsson, L., 2005. Fluxes of $\mathrm{CO}_{2}, \mathrm{CH}_{4}$ and $\mathrm{N}_{2} \mathrm{O}$ from drained coniferous forests on organic soils. For. Ecol. Manage. 210, 239-254. 